\title{
Wat zijn de huidige mogelijkheden voor vergoeding van preventie uit de basisverzekering en wat zijn nieuwe kansen?
}

\author{
Aldien Poll \\ Published online: 21 February 2019 \\ (C) The Author(s) 2019
}

Een reden voor huisartsen om weinig aan 'primaire' preventie te doen was het ontbreken van vergoeding hiervoor. In toenemende mate biedt de zorgverzekering wél de mogelijkheid om individuele preventieve zorg, gericht op het voorkomen van chronische aandoeningen, te vergoeden. Hieronder volgt een overzicht van de mogelijkheden. Wij laten hierbij specifieke preventieve zorg door de huisartsenpraktijk, zoals het bevolkingsonderzoek naar baarmoederhalskanker of de griepprik, achterwege.

De bekostiging van preventie in de eerste lijn is bijzonder gefragmenteerd: een beetje via het inschrijftarief, wat via de consulten en ketentarieven, een klein beetje via aanvullende verzekeringen of met extra subsidies van de gemeente. Veel professionals zijn niet op de hoogte van de mogelijkheden, zijn ten gevolge van de fragmentatie minder geïnteresseerd in preventie en bieden vooral behandelingen en verwijzingen naar de tweede lijn aan.

Overzicht van financieringsmogelijkheden voor preventie vanuit de huisartsenpraktijk

\section{Consulten}

In beginsel kunnen huisartsen consulten in rekening brengen waarin ze mensen adviseren over gezond gedrag. Als veel consulten zouden worden besteed aan preventie, zou dat via de grens van het macrobudget ten koste gaan van de mogelijkheden om andere zorg te leveren. De Landelijke Huisartsen Vereniging staat dan ook niet direct te springen om huisartsen een gro-

\footnotetext{
A. Poll $(\bowtie)$

Pharos landelijk expertisecentrum gezondheidsverschillen, Utrecht, Nederland

info@aldien.nl
}

tere rol bij preventie te laten spelen zolang daar geen extra budget voor komt.

\section{Ketentarieven}

Via de ketenzorgtarieven voor kwetsbare ouderen, diabetes, astma, COPD, hartvaataandoeningen en depressie wordt specifieke preventie van complicaties van deze aandoeningen vergoed. De uitvoering wordt vaak ter hand genomen door een praktijkondersteuner (poh). Het ketentarief kan alleen gedeclareerd worden als daarvoor een contract is gesloten met de zorgverzekeraar. Meestal zijn huisartsen hiervoor aangesloten bij een zorggroep, die deze contracten regelt.

\section{Inschrijftarieven}

In een aantal gevallen wordt de inzet van een poh in de praktijk vergoed via het inschrijftarief dat huisartsen ontvangen voor alle ingeschreven patiënten/ verzekerden en niet via het ketentarief. Dit geldt bijvoorbeeld voor de ondersteuning van ggz-patiënten, die ook kan bestaan uit preventieve begeleiding.

\section{Specifieke preventieprogramma's}

De huisarts kan ook verwijzen naar specifieke preventieprogramma's, zoals 'Stoppen met Roken' of 'Bewegen na een hartinfarct', 'Bewegen met of na kanker' of 'Depressiepreventie bij risicogroepen'. Enkele programma's worden uit de basisverzekering vergoed, andere uit aanvullende verzekeringen en weer andere via het sociaal domein, bijvoorbeeld via de GGD of speciale subsidies van de gemeente. Hierbij kan gedacht worden aan 'Welzijn op Recept' (https:// welzijnoprecept.nl/). In sommige gemeenten kunnen 
op verwijzing van de huisarts mensen deelnemen aan sociale programma's tegen eenzaamheid.

\section{Tarief voor Gecombineerde Leefstijlinterventies}

Sinds dit jaar kan de huisarts een Gecombineerde Leefstijlinterventie (GLI) aanbieden aan mensen met een gewichtsgerelateerd gezondheidsrisico (GGR). De interventie beslaat een begeleidings- en onderhoudsperiode van twee jaar. Het daarvoor ontwikkelde tarief kan alleen gedeclareerd worden als de GLI is goedgekeurd door het RIVM en wanneer hiervoor een contract is gesloten met de verzekeraar. Dit contract zal worden gesloten met de reeds bestaande zorggroepen, niet met een individuele huisarts. De GLI wordt begeleid door een leefstijlcoach, die door de zorggroep wordt gecontracteerd. Er is voor 2019 6,5 miljoen euro vrijgemaakt en voor de jaren daarna 9 miljoen. VWS monitort of dit bedrag voldoet. Er wordt vanuit gegaan dat ongeveer 5\% van de doelgroep zal deelnemen (zie het artikel Zorgverzekeraars en preventie: implementatie van de GLI's in dit nummer) Het betreft dan zo'n 8000 mensen. De individuele huisarts ontvangt voor het verwijzen en het onderhouden van contacten met de aanbieder van de GLI geen vergoeding.

Er zijn grote groepen mensen bij wie overgewicht in verband staat met chronische stress, armoede, schulden, werkloosheid en/of laaggeletterdheid. Bij het inzetten van de GLI moet rekening worden gehouden met deze onderliggende oorzaken. Gebeurt dit niet, dan bestaat het risico dat de interventie voor een flink aantal mensen minder effectief is. Aandacht voor stressreductie, schuldhulpverlening, (sociale) participatie en armoede is bij hen noodzakelijk om tot leefstijlverandering te kunnen komen. Dit vraagt om een netwerk waarin huisartsen en leefstijlcoaches samenwerken met professionals uit het sociale domein (schuldhulpverlening, werk en inkomen of sociale participatie). Het vormen van dit netwerk is niet eenvoudig en is momenteel niet duidelijk bij een of meer partijen belegd.

\section{Innovaties in financiering; het all-in tarief}

Er zijn innovaties mogelijk waarbij gebruik wordt gemaakt van een relatief nieuwe prestatieomschrijving van de NZA. Verschillende huisartsenpraktijken experimenteren daarmee, bijvoorbeeld de gezondheidscentra van Arts en Zorg, die dit nieuwe tarief met Menzis hebben afgesproken.

In overleg met verzekeraars wordt afgesproken dat begeleiding en zorg in de huisartsenpraktijk geheel wordt vormgegeven zoals de huisarts dat het beste vindt [1]. De zorg blijft volgens de stand van de wetenschap geboden worden, maar er is ruimte om gepersonaliseerde zorg te bieden, rekening houdend met de context van een patiënt. Er is ook meer tijd voor preventie en voor het coördineren van samenwerking met bijvoorbeeld het sociaal wijkteam.

Er is dus een all-in tarief voor deze vorm van zorgverlening in de huisartsenpraktijk, dat alleen gedeclareerd kan worden als hier een contract voor is.

\section{Nieuwe kansen}

Nieuwe ontwikkelingen bieden kansen voor professionals om meer persoonsgerichte zorg te bieden en om beter samen te werken. Preventie kan hierdoor een betere plek krijgen in het zorgaanbod.

\section{Regionale organisatie van de eerste lijn}

Zorgverzekeraars willen sinds dit jaar contracten over de organisatie en infrastructuur van de eerste lijn alleen sluiten met grotere regionale zorggroepen. Gelden die nu nog naar gezondheidscentra gaan, gaan dan naar de regionale groepen. Deze groepen zullen op hun beurt de regionale zorgverleners als 'onderaannemers' contracteren. De bedoeling van deze nieuwe regionale structuren is dat er beter wordt samengewerkt in de eerste lijn en met het sociaal domein, en dat er meer vrijheid komt voor persoonsgerichte zorg, inclusief preventie.

\section{Preventiecoalitie, Huisartsenakkoord, Preventieakkoord}

Op beleidsniveau zijn wensen uitgesproken om preventie een prominentere plaats te geven in de eerste lijn. Er zijn tot op heden geen aparte gelden vrijgemaakt voor preventie, anders dan voor de GLI (zie hierboven).

Er is onder de naam 'Preventiecoalities' door VWS geld beschikbaar gesteld om de samenwerking tussen gemeenten en de eerste lijn rond preventie te verbeteren. Er is daarbij geen geld beschikbaar gesteld om de feitelijke preventie of zorg te vergoeden. Het gaat hier dus om het afstemmen van verschillende bestaande mogelijkheden binnen de huidige wet- en regelgeving (Wmo, Zorgverzekeringswet, Jeugdwet, Participatiewet).

Vanuit het Huisartsenakkoord wordt het budget voor huisartsenzorg met 471 miljoen euro uitgebreid. Onderdeel van de uitbreiding geldt de multidisciplinaire zorg en zorg aan mensen in achterstandswijken. Preventie wordt in het akkoord niet apart genoemd.

Er zijn drie preventieakkoorden gepresenteerd van het ministerie van VWS voor 2019-2022: voor overgewicht, roken en overmatig alcoholgebruik. De doelstellingen en aanpak zijn opgesteld door vele deskundigen uit het veld. Het is op dit moment niet duidelijk of er ook budgetten aan de akkoorden worden gekoppeld en wat dit voor huisartsenpraktijken gaat betekenen. 


\section{Toekomstperspectief}

De regionale organisaties zullen flinke budgetten krijgen om de zorg in de eerste lijn beter te organiseren en aan te passen aan de behoeften van de verschillende groepen patiënten. Die behoeften bestaan bij veel patiënten in de eerste lijn niet alleen uit medische zorgverlening, maar ook uit maatschappelijke ondersteuning, vaak in combinatie. Een patiënt bij de huisarts is tegelijkertijd een inwoner van een gemeente met recht op maatschappelijke ondersteuning. De coördinatie tussen de medische zorgverlening en maatschappelijke ondersteuning kan mogelijk georganiseerd worden door die regionale organisaties. De gemeente kan dit stimuleren door mee te financieren, bijvoorbeeld met een bedrag per inwoner. Dat is in het belang van de patiënten met gecombineerde zorgbehoeften en biedt de gemeente de mogelijkheid om mee te sturen in de nieuwe eerstelijnsorganisaties - een eenvoudige manier om schotten te doorbreken.

Open Access This article is distributed under the terms of the Creative Commons Attribution 4.0 International License (http://creativecommons.org/licenses/by/4.0/), which permits unrestricted use, distribution, and reproduction in any medium, provided you give appropriate credit to the original author(s) and the source, provide a link to the Creative Commons license, and indicate if changes were made.

\section{Literatuur}

1. Nyst E. Bruins bezoekt huisarts Jung in Afferden. 2018. https://www.medischcontact.nl/nieuws/laatste-nieuws/ artikel/bruins-bezoekt-huisarts-jung-in-afferden.htm (Gecreëerd: 22 jun 2018), Med Contact.

\section{Voorkomen is beter, maar ook lastig!}

\section{Anja Koornstra}

Published online: 14 February 2019

(C) The Author(s) 2019

Preventieve zorg - het lijkt een contradictio in terminis. Preventie gaat toch voor de zorg uit? Maar tegelijk weten we dat zorgverleners vaak een heel goede relatie met hun patiënten/cliënten hebben en dat ze weten wat medisch gezien nodig is om het (verder) ontwikkelen van ziekte te voorkomen. Ook weten we dat de meeste patiënten/cliënten van zorgverleners juist verwachten dat ze zich ermee bemoeien. 'De dokter zegt niets van mijn overgewicht/roken/..., dus het valt nog wel mee.' En toch komt preventie in de zorg nog maar beperkt tot stand. Aldien Poll heeft een prachtig overzicht gemaakt van de mogelijkheden om in de (eerste-

\footnotetext{
A. Koornstra ( $\bowtie)$

GGD GHOR Nederland, Utrecht, Nederland

akoornstra@ggdghor.nl
}

lijns)zorg preventie een plek te geven. Zijn deze mogelijkheden voldoende?

\section{Basis}

Poll geeft aan dat er al mogelijkheden zijn om preventieve zorg te bieden, onder meer via specifieke programma's, zoals stoppen met roken. Desgevraagd blijkt dat stoppen-met-rokenprogramma minder dan 15.000 keer per jaar bij de zorgverzekeraars te worden gedeclareerd! Terwijl we weten dat in Nederland elk jaar circa 1 miljoen keer een stoppoging wordt ondernomen. Het complete en evidence-based programma lijkt dus maar nauwelijks te worden gebruikt. Daarom maak ik me ook zorgen over de mate waarin de Gecombineerde Leefstijlinterventie (GLI), die sinds dit jaar kan worden aangeboden, zal worden benut. Ik 